\title{
PENGARUH SUHU, KADAR GARAM DAN WAKTU PENGOLAHAN BAKASANG IKAN CAKALANG (Katsuwonus pelamis) TERHADAP PARAMETER FREE FATTY ACID
}

\author{
Ibnu Darmawan Syamsi ${ }^{1 *}$, Feti Fatimah ${ }^{1}$ dan Audy Denny Wuntu ${ }^{1}$ \\ ${ }^{1}$ Jurusan Kimia Fakultas Matematika dan Ilmu Pengetahuan Alam Universitas Sam Ratulangi, \\ Jl. Kampus Unsrat, Kleak, Manado 95115 Sulawesi Utara
}

\begin{abstract}
ABSTRAK
Bakasang adalah produk fermentasi yang dibuat dari jeroan ikan. Dalam penelitian ini bertujuan mengetahui pengaruh suhu, kadar garam dan waktu terhadap pengolahan bakasang ikan cakalang dibuat dengan berbagai kondisi pengolahan. Analisis yang dilakukan dengan menggunakan parameter FFA pada setiap sampel. Berdasarkan penelitian yang dilakukan kadar FFA tertinggi yaitu dengan suhu $30{ }^{\circ} \mathrm{C}$, kadar garam $10 \%$ dan waktu fermentasi selama 15 hari dengan kadar FFA sebesar 4,888 \% dan kadar FFA terendah yaitu dengan suhu $50{ }^{\circ} \mathrm{C}$, kadar garam $20 \%$ dan waktu fermentasi 1,6 hari dengan kadar FFA sebesar $1.156 \%$. Tujuan dari penelitian ini adalah untuk menentukan pengaruh suhu, kadar garam dan waktu pengolahan (variabel independen) terhadap parameter FFA (variabel dependen), maka diperlukan beberapa metode statistika, pertama yaitu uji korelasi suhu, kadar garam dan waktu (variabel independen) terhadap kadar FFA (variabel dependen) dengan hasil penelitian, berturut-turut 56,6\%; 29,6\%; dan 60,1\%, selanjutnya adalah uji analisis varians (ANOVA), ANOVA dilakukan pada $95 \%$ confidence interval dengan nilai signifikansi $\alpha=0,05$, hasil signifikansi untuk variabel suhu, kadar garam dan waktu adalah 0.00 .
\end{abstract}

Kata kunci: Bakasang, ikan cakalang, ANOVA, kadar FFA

\begin{abstract}
Bakasang is a fermented product made from fish innards. This research aims to determine the effect of temperature, salinity and time on the processing of Skipjack Tuna Fish bakasang made with various processing conditions. The analysis was carried out using FFA parameters in each sample. Based on the research, the highest FFA level is at $30^{\circ} \mathrm{C}$ temperature, $10 \%$ salinity and 15 days of fermentation time with FFA level of 4.888 $\%$ and the lowest FFA level is at $70{ }^{\circ} \mathrm{C}$ temperature, $20 \%$ salinity and 1.6 day of fermentation time with FFA level of $1.156 \%$. The aim of this research is to determine the effect of temperature, salinity and processing time (independent variables) on the FFA parameter (dependent variable), so some statistical methods are needed, first, the correlation test of temperature, salinity and processing time (independent variable) on FFA level (dependent variable) with the research results, respectively $56.6 \% ; 29.6 \%$; and $60.1 \%$, next is the analysis of variance (ANOVA) test, ANOVA was carried out at 95\% confidence intervals with a significance value of $\alpha=$ 0.05 , variable significance for temperature, salinity and time was 0,00 .
\end{abstract}

Keywords: Bakasang, skipjack tuna fish, ANOVA, FFA level

\section{PENDAHULUAN}

Indonesia memiliki sumber daya hayati laut yang sangat besar dengan kandungan berbagai macam jenis makhluk hidup di dalamnya. Kekayaan hayati tersebut diantaranya adalah ikan yang mempunyai manfaat dalam bidang kesehatan karena ikan memiliki kandungan gizi yang tinggi serta dapat memberikan keuntungan dari segi ekonomi dengan nilai jual yang tinggi. Kandungan gizi yang utama pada ikan adalah protein dan asamasam lemak esensial yang sangat berguna bagi

\footnotetext{
Korespondensi :

Telepon: +62 821-9504-3520

Email: ibnusyamsi97@gmail.com

DOI: https://doi.org/10.35799/cp.12.2.2019.27430
}

kesehatan manusia (Hafiludin, 2011). Hasil laut yang dijumpai salah satunya ikan cakalang (Katsuwonus pelamis). Pada umumnya, masyarakat lebih banyak mengolah ikan cakalang dari dagingnya saja sedangkan jeroannya jarang digunakan.

Pengolahan hasil perikanan diikuti dengan produksi limbah yang tinggi, seperti limbah hasil produksi filet ikan berupa kepala ikan, jeroan, dan tulang ikan. Jeroan ikan cakalang memiliki bobot 10-15\% dari biomassa ikan (Bhaskar dan Mahendrakar, 2008). Produksi jeroan ikan yang besar ini perlu diimbangi usaha penanganan dan pemanfaatan limbah jeroan ikan tersebut menjadi 
produk yang lebih bernilai tambah. Kualitas nutrisi limbah jeroan ikan sebagai bahan baku pangan sangat tergantung pada sistem pengolahan bahan baku. Produksi ikan cakalang rata-rata diperkirakan sekitar 498,23 ton/tahun. Hal ini jika dibiarkan akan berdampak pada lingkungan. Karena itu, kita perlu memanfaatkan limbah jeroan ikan cakalang sebagai bahan baku pangan (Apu, 2017).

Produk-produk fermentasi ikan banyak dijumpai di Asia Tenggara. Bakasang adalah salah satu produk tradisional fermentasi bergaram dari ikan yang banyak dijumpai di beberapa daerah di Indonesia terutama Sumatera Selatan, Kalimantan Selatan, dan Sulawesi Utara. Pada umumnya produk ini dibuat dengan mencampurkan ikan, nasi dan garam dalam wadah tertutup dan selanjutnya dilakukan proses fermentasi pada suhu ruang antara 5 sampai 7 hari. Bakasang yang dihasilkan mempunyai karakteristik daging ikan seperti ikan segar dengan daging ikan yang semakin kenyal, rasa asam asin khas bakasang dengan aroma tertentu (Wikandari dkk., 2012). Produk ini menjadi sangat terintegrasi dengan kebiasaan makan orang Indonesia Timur, terutama orang-orang Manado (di Provinsi Sulawesi Utara). Bakasang biasanya digunakan sebagai penyedap di banyak hidangan atau dicampur dengan cabai merah, tomat, bawang merah dan bawang putih dan kemudian ditumis dengan minyak kelapa. Saus tumis ini dimakan dengan campuran bubur dan sayuran yang disebut tinutuan (Ijong \& Ohta, 1995).

Seperti produk pangan lainnya, ada beberapa parameter yang menjadi indikator terhadap bagus tidaknya kualitas suatu bakasang, salah satunya adalah asam lemak bebas (FFA). FFA menunjukkan sejumlah asam lemak bebas yang dikandung oleh minyak yang rusak karena peristiwa hidrolisis (Aditia dkk., 2014). Menurut Bimbo (1998), dalam standar yang ditetapkan oleh International Fishmeal \& Oil Manufacturers Association (IFOMA), minyak ikan dikatakan memiliki mutu yang bagus apabila memiliki kandungan asam lemak bebas sebesar 1-7\%. FFA terjadi karena adanya proses hidrolisis (Fessenden \& Fessenden, 1992).

Sebelumnya telah dilakukan penelitian tentang evaluasi kualitas bakasang ikan cakalang yang diolah dengan berbagai variasi kadar garam, suhu, dan waktu fermentasi oleh Fatimah dkk. (2017), dengan kadar garam 10-30 \%, suhu 30-70 ${ }^{\circ} \mathrm{C}$, dan waktu fermentasi 5-15 hari.
Pada penelitian ini, beberapa metode statistika digunakan untuk mencapai hasil penelitian yang komprehensif pertama yaitu uji korelasi antar variabel independen terhadap kadar FFA, selanjutnya adalah uji ANOVA yang digunakan untuk menguji signifikansi variabel yang berpengaruh. Penelitian ini bertujuan untuk menganalisis pengaruh suhu, kadar garam dan waktu pengolahan bakasang ikan cakalang terhadap kadar FFA.

\section{BAHAN DAN METODE}

\section{Bahan dan alat}

Bahan-bahan yang digunakan adalah jeroan (usus, hati, jantung dan telur) ikan cakalang segar diambil dari Pasar lokal di Manado, dan jeruk nipis. Bahan-bahan kimia yang digunakan adalah garam dapur $(\mathrm{NaCl})$, fenolftalein 0,5\%, alkohol $95 \%, \mathrm{NaOH}$, dan aquades. Alat-alat yang digunakan adalah papan pengelas, pisau, gunting, wadah tempat sampel uji, botol, blender, erlenmeyer, gelas ukur, timbangan analitik, statif, buret, aluminium foil, hotplate, batang pengaduk, kertas saring, pipet tetes, fermentor.

\section{Pengolahan bakasang ikan cakalang}

Pengolahan bakasan mengikuti prosedur Fatimah dkk. (2017). Jeroan ikan cakalang segar terdiri dari hati, usus, jantung, dan telur. Jeroan ikan dicuci dengan air leding yang mengalir, ditiris, kemudian dilumuri dengan jeruk nipis, dicuci, dan ditiris lagi, diblender, dibungkus ke dalam 15 buah wadah, kemudian disimpan dalam freezer. Kemudian pada waktu fermentasi, sampel bakasang diambil dan dimasukkan ke dalam fermentor, dan dicampur garam dengan variasi konsentrasi: 3,$18 ; 10 ; 20 ; 30 ; 36,82 \%$. Wadah ditutup rapat dan dipanaskan dengan berbagai variasi suhu: 16,$36 ; 30 ; 50 ; 70 ; 83,64{ }^{\circ} \mathrm{C}$ dan variasi waktu fermentasi: 1,$6 ; 5 ; 10 ; 15 ; 18,4$ hari. Bakasang diaduk sekali sehari di dalam fermentor sampai waktu yang ditentukan dan kemudian diambil untuk analisis. Semua sampel dianalisis dengan dua pengulangan.

\section{Uji FFA (BSN, 1998)}

Sebanyak $10 \mathrm{~g}$ sampel ditimbang ke dalam erlenmeyer kemudian ditambahkan $100 \mathrm{~mL}$ alkohol 95\% netral, dipanaskan diatas hot plate selama 10 menit, setelah terpisah 2 fase, filtrat diambil dan ditetesi indikator PP 0,5\% sebanyak 10 tetes. Kemudian dititrasi dengan $\mathrm{NaOH} \mathrm{0,1} \mathrm{N}$ hingga timbul warna merah muda yang tidak 
berubah selama 15 detik. Persentase FFA dihitung berdasarkan persamaan berikut:

$$
\% F F A=\frac{M \times V \times T}{1000 \times m} \times 100 \%
$$

Keterangan: $\mathbf{M}=$ Bobot molekul asam lemak $(328,488 \mathrm{~g} / \mathrm{mol}), \mathrm{V}=$ Volume $\mathrm{NaOH}$ yang diperlukan dalam titrasi $(\mathrm{mL}), \mathrm{T}=$ Normalitas $\mathrm{NaOH}, \mathrm{m}=$ Bobot sampel $(\mathrm{g})$

\section{Analisis data}

Dalam penelitian ini analisis data hubungan antara variabel terhadap respon dilakukan dengan uji korelasi, selanjutnya dilakukan analisis signifikansi.

\section{HASIL DAN PEMBAHASAN}

\section{Kadar FFA}

Berdasarkan hasil pengujian FFA bakasang ikan cakalang, yang memiliki kadar FFA tertinggi yaitu dengan suhu $30{ }^{\circ} \mathrm{C}$, kadar garam $10 \%$ dan waktu fermentasi selama 15 hari dengan kadar FFA sebesar $4.888 \%$. Sebaliknya, kadar FFA terendah yaitu dengan suhu $70^{\circ} \mathrm{C}$, kadar garam $20 \%$ dan waktu fermentasi 1,6 hari dengan kadar FFA sebesar $1.156 \%$.

Tabel 1. Hasil analisis kadar FFA dengan berbagai kondisi pengolahan

\begin{tabular}{cccc}
\hline Suhu & Kadar garam & Waktu & $\begin{array}{c}\text { Kadar FFA } \\
(\%)\end{array}$ \\
\hline 30 & 10 & 5 & 3.244 \\
70 & 10 & 5 & 2.31 \\
30 & 30 & 5 & 3.034 \\
70 & 30 & 5 & 1.617 \\
30 & 10 & 15 & 4.888 \\
70 & 10 & 15 & 3.717 \\
30 & 30 & 15 & 4.446 \\
70 & 30 & 15 & 3,181 \\
16.36 & 20 & 10 & 4.621 \\
83.64 & 20 & 10 & 1.453 \\
50 & 3.18 & 10 & 3,263 \\
50 & 36.82 & 10 & 1.275 \\
50 & 20 & 1.6 & 1.156 \\
50 & 20 & 18.4 & 4.135 \\
50 & 20 & 10 & 2.253 \\
50 & 20 & 10 & 2.264 \\
50 & 20 & 10 & 2.387 \\
50 & 20 & 10 & 2.333 \\
50 & 20 & 10 & 2.176 \\
50 & 20 & 10 & 2.225 \\
\hline
\end{tabular}

Menurut Bimbo (1998), dalam standar yang ditetapkan oleh IFOMA, minyak ikan dikatakan memiliki mutu yang bagus apabila memiliki kandungan asam lemak bebas sebesar 1-7\%. Berdasarkan pernyataan tersebut, dengan demikian dapat disimpulkan bahwa bakasang ikan cakalang dengan suhu, kadar garam dan waktu fermentasi dengan berbagai kondisi pengolahan sesuai dengan Tabel 1. masih dalam taraf aman karena tidak melebihi standar yang ditetapkan.

\section{Korelasi antar variabel (suhu, kadar garam} dan waktu) terhadap kadar FFA

Dilakukan uji korelasi untuk mengetahui tingkat hubungan pengaruh masing-masing variabel suhu, kadar garam dan waktu fermentasi. Nilai korelasi antar variabel diperoleh dari hubungan linear $\mathrm{x}$ yang berupa suhu, kadar garam dan waktu fermentasi terhadap nilai y yang berupa kadar FFA. Uji korelasi memiliki nilai -1 hingga +1 . Semakin mendekati -1 atau +1 maka korelasi variabel x terhadap y semakin kuat. Notasi $(+)$ dan (-) berturut-turut menunjukkan hubungan searah atau lurus dan berlawanan arah atau berbanding terbalik. Hasil uji korelasi antara variabel suhu, kadar garam dan waktu fermentasi terhadap kadar FFA disajikan pada Tabel 2. 
Tabel 2. Korelasi tiga variabel proses terhadap bilangan TBA

\begin{tabular}{lc}
\hline \multicolumn{1}{c}{ Variabel $(\mathrm{x})$} & Nilai koefisien $(\mathrm{r})$ \\
\hline Suhu & $0.566^{* *}$ \\
Kadar garam & 0.296 \\
Waktu & $0.601^{* *}$ \\
\hline
\end{tabular}

Keterangan: **Menunjukkan terdapatnya kekuatan korelasi variabel terhadap respon.

Dengan tabulasi silang antara kadar FFA terhadap setiap variabel, maka waktu fermentasi memiliki angka koefisien korelasi paling tinggi terhadap kadar FFA. Dapat dilihat bahwa nilai korelasinya adalah 0,601 dan dibandingkan dengan variasi suhu dan kadar garam yakni -0,566 dan $-0,296$. Sudjana (2002) menyatakan bahwa korelasi memiliki 4 tingkatan yaitu tidak berkorelasi $(0-0,09)$, lemah $(0,1-0,25)$, kuat $(0,26$ $0,49)$ dan sangat kuat $(\geq 0,5)$.

Tabel 2 menunjukkan bahwa waktu fermentasi mempunyai korelasi paling tinggi (tingkatan sangat kuat) di antara variabel lainnya yang mengartikan bahwa waktu fermentasi sangat berpengaruh pada penentuan kadar FFA. Pada suhu fermentasi juga memberikan korelasi (tingkatan sangat kuat) terhadap kadar FFA namun bertanda negatif karena seiring pertambahan suhu maka membuat kadar FFA semakin rendah, begitu juga dengan kadar garam yang memberikan korelasi (tingkatan kuat) bertanda negatif.

\section{Uji signifikansi}

Signifikansi adalah besarnya probabilitas atau peluang untuk memperoleh kesalahan dalam mengambil keputusan. Uji signifikansi melalui pengujian Analysis of Variance (ANOVA) ini bertujuan untuk mengetahui apakah ada pengaruh dari berbagai variabel suhu, kadar garam dan waktu fermentasi terhadap ladar FFA. Selain itu, uji signifikansi dilakukan untuk mengetahui nilai koefisien determinasi (R2) yang menunjukkan kekuatan tingkat kepercayaan terhadap data berdasarkan persamaan linear. Dalam penelitian ini ditetapkan nilai tingkat signifikansi sebesar 0,05 dengan tingkat kepercayaan (confidence level) sebesar 0,95 atau $95 \%$. Hasil uji signifikansi pada penelitian ini disajikan dalam Tabel 3.

Dari Tabel 3 dapat dilihat bahwa berdasarkan nilai signifikansi dari tiga variabel dalam fermentasi bakasang yang memberikan pengaruh signifikan adalah ketiga variabel suhu, kadar garam, dan waktu fermentasi. Nilai signifikansi ketiga variabel tersebut adalah 0,000.
Nilai tersebut kurang dari batas signifikansi yaitu 0,05 atau tingkat kepercayaan 95\%. Pengujian signifikansi ini membuktikan bahwa kadar FFA dipengaruhi oleh variabel suhu, kadar garam, dan waktu fermentasi.

Tabel 3. Hasil pengujian ANOVA

\begin{tabular}{lccc}
\hline Sumber & Df & F & Sig \\
\hline Model & 14 & 215.637 & 0.000 \\
koreksi & 1 & 11974.883 & 0.000 \\
Intersep & 3 & 381.953 & 0.000 \\
Suhu & 3 & 103.832 & 0.000 \\
Kadar Garam & 3 & 376.472 & 0.000 \\
Waktu & 1 & 3.264 & 0.131 \\
$\begin{array}{l}\text { Suhu*Kadar } \\
\text { garam }\end{array}$ & 1 & 0.030 & 0.868 \\
$\begin{array}{l}\text { Suhu*Waktu } \\
\text { Kadar }\end{array}$ & 1 & 0.096 & 0.781 \\
garam*Waktu & 1 & & \\
$\begin{array}{l}\text { Suhu*Kadar } \\
\text { garam*Waktu }\end{array}$ & 1 & 1.045 & 0.354 \\
$\begin{array}{l}\text { Eror } \\
\text { Total }\end{array}$ & 5 & & \\
$\begin{array}{l}\text { Total } \\
\text { dikoreksi }\end{array}$ & 20 & & \\
\hline
\end{tabular}

$$
\mathrm{R}^{2}=0.998\left(\mathrm{R}^{2} \text { disesuaikan }=0.994\right)
$$

Koefisien determinansi $\left(\mathrm{R}^{2}\right)$ memiliki nilai berkisar antara $0-1$. Semakin kecil nilai $\mathrm{R}^{2}$ maka hubungan antar variabel semakin lemah, sebaliknya jika nilai $\mathrm{R}^{2}$ semakin mendekati 1 maka hubungan antar variabel dengan respon semakin kuat. Angka ini akan diubah dalam bentuk persen untuk mempermudah dalam menentukan besar maupun kecilnya pengaruh variabel. Batas penerimaan $R^{2}$ sebesar 0,60 (Sudjana, 2002). Dari Tabel 3, nilai $\mathrm{R}^{2}$ sebesar 0,998 yang artinya bahwa tingkat kepercayaan data pengaruh suhu, kadar garam dan waktu fermentasi bakasang ikan cakalang terhadap kadar FFA sebesar 99,8\%. Pengaruh lain yang tidak dimasukkan ke dalam model atau variabel independen akan mempengaruhi jumlah persentase. Terlihat pada Tabel 3 bahwa $\mathrm{R}^{2}$ disesuaikan merupakan $\mathrm{R}$ yang telah disesuaikan sebesar 0,994 dengan tingkat kepercayaan sebesar 99,4\%. Angka ini juga menunjukkan pengaruh variabel independen terhadap variabel dependen.

\section{KESIMPULAN}

Dalam fermentasi bakasang ikan cakalang (Katsuwonus pelamis) ketiga variabel memberikan pengaruh terhadap kadar FFA, 
variabel suhu memberikan pengaruh sebesar $56,6 \%$, variabel kadar garam memberikan pengaruh sebesar $29,6 \%$ dan variabel waktu fermentasi memberikan pengaruh sebesar $60,1 \%$, dan untuk nilai signifikansi untuk variabel suhu, kadar garam dan waktu adalah 0.000 , maka baik suhu, kadar garam dan waktu mempunyai pengaruh signifikan yang besar terhadap kadar FFA, dengan signifikansi tiga variabel $<0.05$, pengujian signifikansi ini membuktikan bahwa kadar FFA sangat dipengaruhi oleh ketiga variabel ini.

\section{DAFTAR PUSTAKA}

Aditia, R.P., Darmanto, Y.S. \& Romadhon. 2014. Perbandingan mutu ikan kasar yang di ekstrak berbagai jenis ikan yang berbeda. Jurnal Pengolahan dan Bioteknologi Hasil Perikanan. 2(3), 55-60.

Apu, R.L. 2017. Pemanfaatan limbah jeroan ikan cakalang (Katsuwonus pelamis) sebagai bahan subtitusi tepung ikan terhadap kinerja pertumbuhan ikan nila (Oreochromis niloticus). Tesis. Universitas Hasanuddin, Makassar.

Badan Standardisasi Nasional. 1998. SNI 013555-1998: Cara uji minyak dan lemak. Badan Standardisasi Nasional, Jakarta.

Bhaskar, N. \& Mahendrakar, N.S. 2008. Protein hydrolisate from visceral waste protein of catla (Catla catla): Optimization of hydrolysis condition for a commercial neutral protease. Bioresource Technology. 99(10), 4105-4111.
Bimbo, A.P. 1998. Guidelines for characterizing food-grade fish oil. INFORM. 9(5), 473483.

Fatimah, F. Pelealu, J.J., Gugule, S., Yempormase,H.V. \& Tallei, T.E. 2017. Quality evaluation of bakasang processed with variation of salt concentration, temperature and fermentation time. Pakistan Journal of Biological Sciences. 20(11), 543-551.

Fessenden, R.J. \& Fessenden, J.S. 1992. Kimia organik jilid II. Jakarta: Erlangga.

Hafiludin. 211. Karakteristik proksimat \& kandungan seyawa kimia daging putih \& daging merah ikan tongkol (Euthynnus affinis). Jurnal Kelautan. 4(1), 1-10.

Ijong, F.G.\& Ohta, Y. 1995. Amino acid compositionsof bakasang, a traditional fermented fish sauce from Indonesia. Journal of Food Science and Technology. 28(2), 236-237.

Sudjana. 2002. Desain dan analisis eksperimen edisi keempat. Bandung: PT Tarsito.

Wikandari, P.R., Suparno, Marsono Y. \& Rahayu, E.S. 2012. Karakterisasi bakteri asam laktat proteolitik pada bekasam. Jurnal Natur Indonesia. 14(2), 120-125. 